\begin{tabular}{|c|c|}
\hline \multirow{3}{*}{ 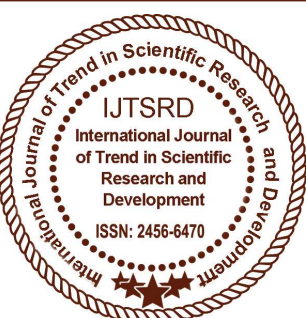 } & $\begin{array}{l}\text { International Journal of Trend in Scientific } \\
\text { Research and Development (IJTSRD) }\end{array}$ \\
\hline & International Open Access Journal \\
\hline & ISSN No: 2456 - 6470 | www.ijtsrd.com | Volume - 2 | Issue - 5 \\
\hline
\end{tabular}

\title{
A Study on Effectiveness of Training and Development with Reference to Alpha Global Sourcing Pvt. Ltd, Banglore
}

\author{
N. Veena ${ }^{1}$, P. Asha Latha ${ }^{2}$ \\ ${ }^{1}$ Associate Professor, ${ }^{2}$ Assistant Professor \\ Mother Theresa Institute of Management, Palamaner, Andhra Pradesh, India
}

\begin{abstract}
Training and development is vital protective device for improving employee performance and organizations retain accumulative training budget on yearly basis with believe that it will earn them competitive edge. The main objective of this study is to examine the effectiveness of training and development on employees' performance and organization competitive advantage in the Alpha global sourcing Pvt Ltd. Descriptive research method was adopted for this study using hundred valid questionnaires which were completed by using simple random sampling technique. The data collected were judiciously examined using descriptive statistics to represent the raw data in a meaningful manner. The results show that strong relationship exists between training and development, employees' performance and competitive advantage. Summary of the findings indicates that there is strong relationship between the tested dependent variable and independent construct. However, management should not relent in their quest to train their staff to develop new ideas that will keep improving and retaining employee performance.
\end{abstract}

Keywords: training, development, performance, competitiveness

\section{INTRODUCTION}

The existence of any organization in the competitive society lies in its capability to train its human resource to be creative, innovative, resourceful who will invariably enrich performance and rise competitive advantage. For an organization, training and development are important as well as organizational growth, because the organizational growth and profit are also dependent on the training. But the training is not a core of organizational development. It is a function of the organizational development. It plays an important role in the effectiveness of organizations and to the experiences of people in work. Training has implications for productivity, health and safety at work and personal development. All organizations employing people need to train and develop their staff. In this regard, this study aimed to contribute to the existing knowledge particularly in the sphere of capacity development. It is to this end that this paper seeks to /critically examine the effectiveness of training and development on employees' performance and organization competitiveness.

\section{Review of Literature:}

According To Fizzah (2011), the purpose of the research is to find out how training and development effect organizational performance and to find out what is the impact of training and development in organization. Training and development is important for the employees in organization, it helps the employees to improve their skills and to give a good performance in workplace.

According to Shelley Frost, Demand Media Training is a crucial component in preparing new employees for their positions and keeping existing employees current on critical information. To be effective, a training program needs a specific purpose with appropriate training methods. According to

\section{Henry Ongori (2011), Jennifer Chishamiso} Nzonzo, Training and development has become an issue of strategic importance. Although many scholars have conducted research on training and development practices in organizations in both developing and developed economies, it is worth mentioning that 
most of the research has concentrated on the benefits of training in general

According to Iftikhar Ahmad and Sirajud Din (2009), Training and development is adopted by organizations to fill the skill gap of employees. Training evaluation must be appropriate for the person and situation. Evaluation will not ensure effective learning unless training is properly designed.

According to Bates and Davis (2010), Usefulness of training programme is possible only when the trainee is able to practice the theoretical aspects learned in training programme in actual work environment. They highlighted the use of role playing, cases, simulation, mediated exercises, and computer based learning to provide exposure to a current and relevant body of knowledge and real world situations

\section{Objectives of the study}

1. To study the different methods of training programmes conducted in Alpha global sourcing Pvt Ltd.

2. To study the effectiveness of training programme in Alpha global sourcing Pvt Ltd.

3. To know the satisfaction level of employees towards training programme.

\section{Research design /Methodology}

1. Sampling design-Primary data collection: data collected through survey and questionnaires. Secondary data collection: data collected through industry profile, journals, and reports in website.

2. Data analysis tool-Data analyzed and validated by used SPSS package to compute various statistical values wherever it is necessary. Suitable diagrams are used to exhibit the analyzed data.

3. Sample size-100 employees

4. Sample unit-Employees of Alpha global sourcing Pvt Ltd

\section{Need of the Study}

The need of Training and Development to any organization is predominant. The first step of the process of training and development is identification of the organizational needs for trained manpower, both present and future.

The productiveness of an employee is the important factor for the employer, because the income or profit of the organization and employer is depends on the employees' productiveness.
Begin by assessing the current status of the company; how it does, what it does best and the abilities of your employees to do these tasks. This analysis will provide some benchmarks against which the effectiveness of a training program can be evaluated. The organization or an employer should know where it wants to be in its long-range strategic plan and organizational need is a training program to take the organization from current situation to developed step.

Secondly, consider whether the organization is financially committed to support the training efforts. If not, any attempt to develop a solid training program will fail.

Next, determine exactly where training is needed. It is foolish to implement a companywide training effort without concentrating resources where they are needed most. An internal audit will help point out areas that may benefit from training. Also, a skills inventory can help determine the skills possessed by the employees in general. This inventory will help the organization determine what skills are available now and what skills are needed for future development.

In summary, the analysis should focus on the total organization and should identify where training is needed and where it will work within the organization.

\section{Scope of the Study}

- Training and development covers the area of organization culture, climate, knowledge management, and organization on change, technology processes, implementation strategy, rules and regulation skills, quality maintenance.

Higher standards of work performance

Greater understanding and appreciation of factors affecting work performance

$>$ Sharing of ideas and dissemination of good practice

$>$ Effective management and implementation of change

$>$ Encouragement of team spirit

$>$ Increased motivation and job satisfaction for the individual

\section{Limitations of Training \& Development}

$>$ Non-Response Error- Due to work load, the respondents (SAO, AAO, etc.,) could not spare much time to respond. 
International Journal of Trend in Scientific Research and Development (IJTSRD) ISSN: 2456-6470

$>$ Response Error- Huge space between what respondents say and do. Due to confidentiality, accurate response was not revealed by some of the respondents.

> Sample May Be Biased- The study is being done purely on the respondents ${ }^{\text {ee }}$ response in the questionnaire and interviews that may be biased.

$>$ Limited Duration- The project duration was confined to 30 days only.

Academic Purpose- The study is purely for academic purpose having no possibility to study beyond scope

\section{Data Analysis and Interpretation}

Table 1.Reason for Attending the Training Programme by the Employee

\begin{tabular}{|c|c|c|}
\hline OPTIONS & $\begin{array}{c}\text { RESPON } \\
\text { DENS }\end{array}$ & $\begin{array}{c}\text { PERCEN } \\
\text { TAGE }\end{array}$ \\
\hline $\begin{array}{c}\text { Improving the } \\
\text { productivity }\end{array}$ & 20 & $20 \%$ \\
\hline $\begin{array}{c}\text { Improvingthe knowledge } \\
\text { to work in the company }\end{array}$ & 30 & $30 \%$ \\
\hline $\begin{array}{c}\text { Improving the skills } \\
\text { needed to perform the job }\end{array}$ & 40 & $40 \%$ \\
\hline All of the above & 10 & $10 \% \mathrm{C}$ \\
\hline
\end{tabular}

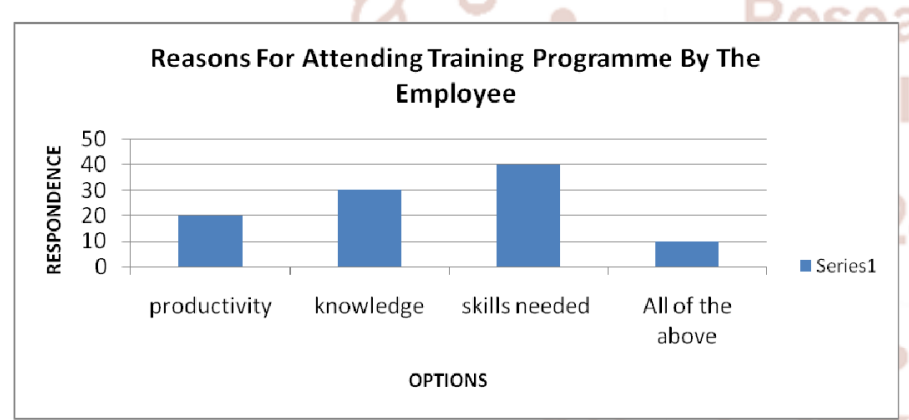

\section{Interpretation:}

From the above table $20 \%$ of employees agreed that, training should improve the organizational productivity, $30 \%$ of employees agreed that, it should improve the knowledge, $40 \%$ of employees agreed that, it improve the skills needed to perform the job, and $10 \%$ of employees agreed all the above.

Table2. Methods of Training and Development

\begin{tabular}{|c|c|c|}
\hline Options & $\begin{array}{c}\text { No. of } \\
\text { respondents }\end{array}$ & Percentage \\
\hline $\begin{array}{c}\text { On job } \\
\text { training }\end{array}$ & 69 & 69 \\
\hline $\begin{array}{c}\text { Off the job } \\
\text { training }\end{array}$ & 31 & 31 \\
\hline
\end{tabular}

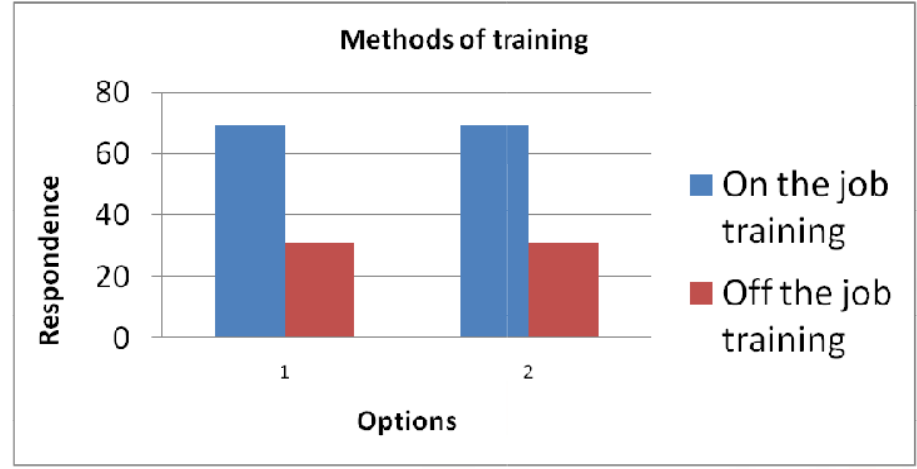

Interpretation: From the above table 69\% participated in on the job training. And 31\% participated in off the job training. So the company following both On-the-job and Off-the-job methods.

Table3. Organizational Behavior.

\begin{tabular}{|c|c|c|}
\hline Options & Responsence & Percentage \\
\hline $\begin{array}{c}\text { Workplace } \\
\text { communication }\end{array}$ & 29 & 29 \\
\hline Problem Solving & 17 & 17 \\
\hline $\begin{array}{c}\text { Work place Safety } \\
\text { Management }\end{array}$ & 21 & 21 \\
\hline $\begin{array}{c}\text { Reducing Stress in } \\
\text { the Workplace }\end{array}$ & 33 & 33 \\
\hline
\end{tabular}

T\&D enrich employee understanding on the sub parts of organizational behavior.

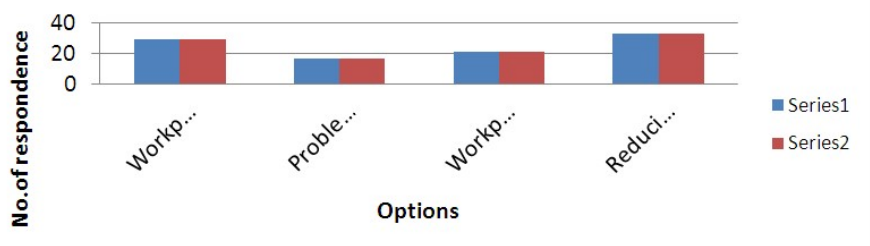

Interpretation: From the above table 29\% says that training improves work place communication, $17 \%$ says that it enhance the problem solving capacity, $21 \%$ says that it improves workplace management,33\% says that it reduces stress in the workplace. So, it covers all areas.

Table4. Rating the Training Program to Develop Un-Known Areas

\begin{tabular}{|c|c|c|}
\hline Rating & Respondence & Percentage \\
\hline 0 & 5 & 5 \\
\hline 1 & 10 & 10 \\
\hline 2 & 15 & 15 \\
\hline 3 & 20 & 20 \\
\hline 4 & 15 & 15 \\
\hline 5 & 35 & 35 \\
\hline
\end{tabular}


International Journal of Trend in Scientific Research and Development (IJTSRD) ISSN: 2456-6470

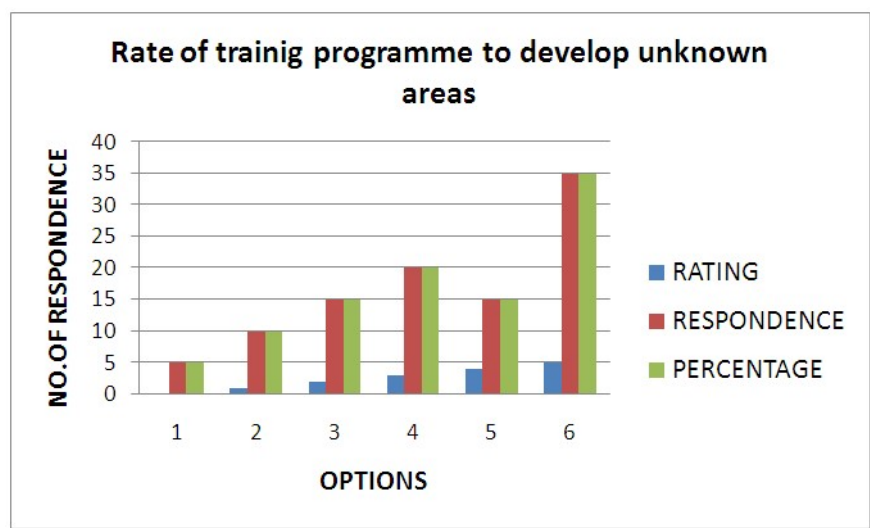

Interpretation: From the above table training develop unknown areas. For that $5 \%$ give rating to $0,10 \%$ give rating to $1,15 \%$ give rating as $2,20 \%$ give rating as $15 \%$ and $35 \%$ give rating as 5 . So training improves skills in unknown areas.

Table 5. Rating Employee Training Programme. Rating Respondence

\begin{tabular}{|l|l|}
\hline 0 & 25 \\
\hline 1 & 22 \\
\hline 2 & 15 \\
\hline 3 & 10 \\
\hline 4 & 16 \\
\hline 5 & 12 \\
\hline
\end{tabular}

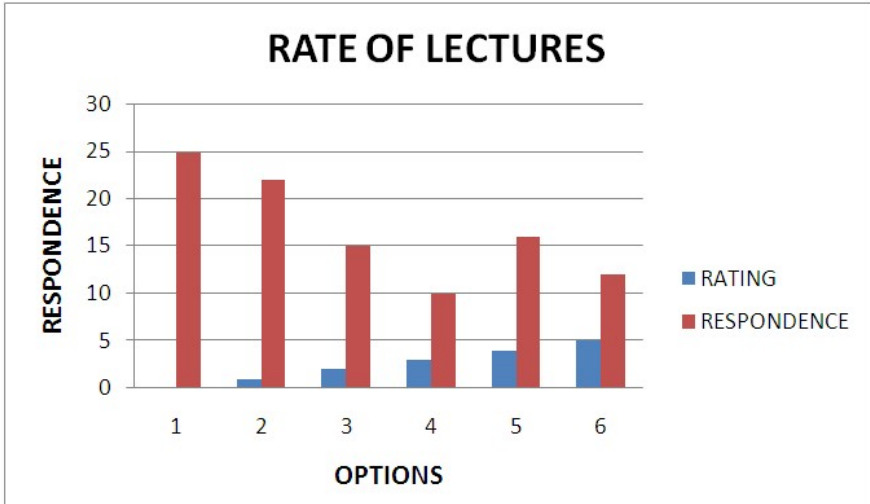

Interpretation: From the above table employees give rating from $0-5$ about enhancing technological skills through lectures. $25 \%$ give 0 rating, $22 \%$ give 1 , $15 \%$ give $2,10 \%$ give $3,16 \%$ give $4 \%, 12 \%$ give 5 .so training through lectures enhance the technological skills.

Table6. The Methods Used In the Training Program to Enrich Skills.

\begin{tabular}{|c|c|c|}
\hline Options & Respondence & Percentage \\
\hline $\begin{array}{c}\text { Presentation } \\
\text { methods }\end{array}$ & 20 & 20 \\
\hline Hands-on methods & 50 & 50 \\
\hline $\begin{array}{c}\text { Group building } \\
\text { methods }\end{array}$ & 30 & 30 \\
\hline
\end{tabular}

Table6. The Methods Used In the Training Program to Enrich Skills.

\begin{tabular}{|c|c|c|}
\hline Options & Respondence & Percentage \\
\hline Presentation methods & 20 & 20 \\
\hline Hands-on methods & 50 & 50 \\
\hline $\begin{array}{c}\text { Group building } \\
\text { methods }\end{array}$ & 30 & 30 \\
\hline
\end{tabular}

\section{T\&D METHODS USED IN THE COMPANY}

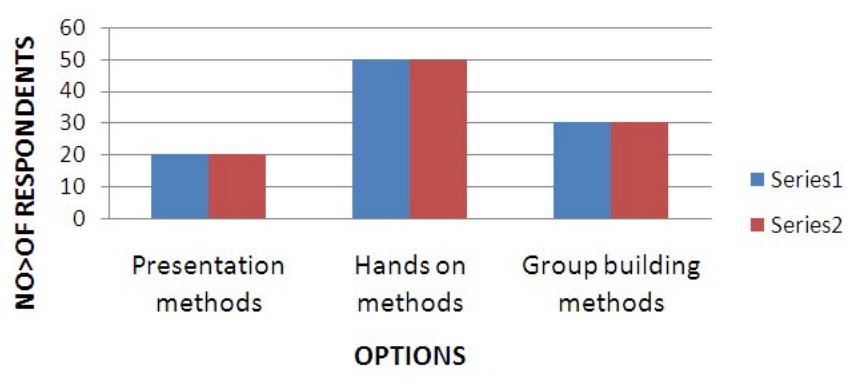

Interpretation: From the above table $20 \%$ vote for presentation methods, $50 \%$ vote for hands on methods. $30 \%$ vote for group building methods. So hand-on-methods enrich skills.

\section{Table7. Learning Objectives Excelled By the Employee.}

\begin{tabular}{|c|c|c|}
\hline Options & Respondence & Percentage \\
\hline $\begin{array}{c}\text { Continuous learning } \\
\text { Knowledge } \\
\text { generation and } \\
\text { sharing }\end{array}$ & 24 & 24 \\
\hline $\begin{array}{c}\text { Encouragement of } \\
\text { flexibility and } \\
\text { experimentation }\end{array}$ & 26 & 26 \\
\hline $\begin{array}{c}\text { Critical systematic } \\
\text { thinking }\end{array}$ & 10 & 10 \\
\hline
\end{tabular}

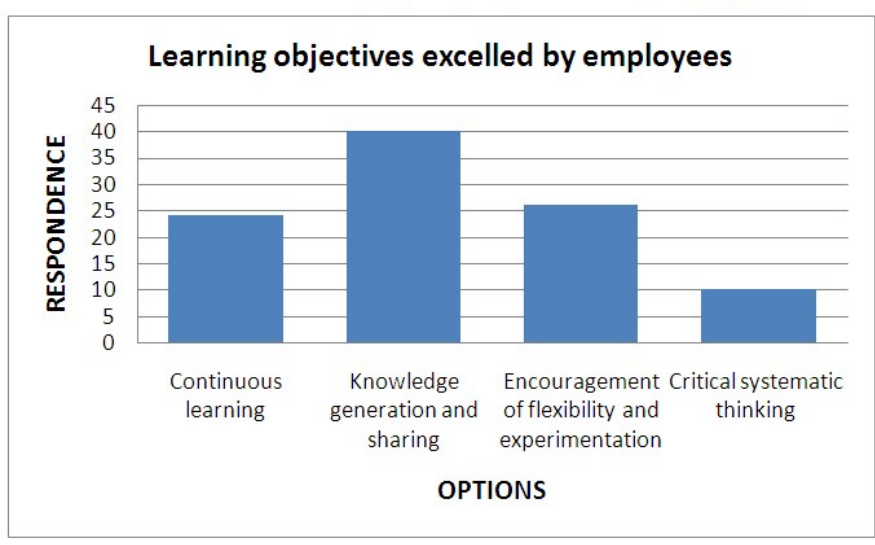


Interpretation: From the above table $24 \%$ of employees give voting as learning objective will give continuous learning, $40 \%$ give on knowledge generation and sharing, $26 \%$ give on flexibility and experimentation, $10 \%$ give as Critical systematic thinking

\section{FINDINGS}

$>79 \%$ OF employees participated in training programme.

$>40 \%$ of employees believe that $\mathrm{T} \& \mathrm{D}$ improves the skills needed to perform the job

$>$ The company follows both on the job and off the job methods. Most employees participated in the on the job method.

$>$ HR department involve in assessing training needs. Department heads

$>$ Helps in assessing the training needs.

$>$ Employees of southern technology satisfied with the training and development programme.

\section{SUGGESTIONS:}

$>$ Trainer, training place, training method, trainee are the major things that should be considered while conducting the training program.

$>$ More improvement in latest knowledge should be added in the training program.

$>$ The in-house-training program can be improved by inviting faculties from various business schools and mostly from various private agencies for the conducting training programs for the employees.

$>$ The faculty's performance was somewhat good, it should be changed, to great extent.

$>$ Training program, was well designed and functioned in systematic way was somewhat extent, it should be changed, to great extent.

$>$ The employee's feedback must be gathered in a proper way.

\section{CONCLUSION:}

Training and Development is very important for any organization. Present project has been conducted in Alpha global sourcing Pvt Ltd Company. This project has been studied from lot of books and gathered required information. Accordingly I have observed the company and compared the scenarios with industrial trends. I found some gaps in the training program which are very small to be considered. But, the predominate cause of the training program is aptly performing in the company. I felt satisfied in acquiring the lot of knowledge in the field of training and development theoretically as well as practically. The project what I have done is reported with all flavors of the processes and procedures submitted successfully.

\section{REFERENCES}

1. Abdul Hameed Aamer Waheed (2011): Employee Development and Its Affect on Employee Performance a Conceptual Frameworkll.

2. Atif et al. (2010): - Employee Retention Relationship to Training and Development: A Compensation Perspective

3. Jelena Vemic (2007): - Employee Training and Development and the Learning Organizationll. Facta Universities Series; Economics and Organization

4. Kate Hutchings, Cherrie J. Zhu, Brain K, Cooper, Yiming Zhang and Cajun Shao (2009): -Perceptions of the effectiveness of training and development of ,grey-collar workers in the People's Republic of Chinall.

5. Rama V. Devi \& Nagurvali Shaik (2012): -Training \& Development - A Jump Starter for Employee Performance and Organizational Effectivenessll. International Journal of Social Science \& Interdisciplinary

6. Rohan, S. \& Madhumita, M. (2012): - Impact of Training Practices on Employee Productivity: A Comparative Studyll. Interscience Management Review

\section{Books:}

1. Human Resource Management- Rao V. S. P.

2. Human resource Management- Lawrence $\mathrm{S}$. Kleeman 